\title{
The Textual Space and Space of the Text in Prévost
}

\author{
Jean Norgaisse \\ Spelman College
}

$\mathrm{T}$

he representation of space in the body of the literary text might escape the attention of the naive reader of Prévost's novels. This space is for the experienced reader a matter for serious thought, since it represents the imaginary territory in which one discovers the interwoven relations among the literary places. The space, which covers the span of the text, in its content, fits into the creative procedures of the novelist. It goes without saying that all Prévostian spaces are planned according to a precise order in the literary composition. Such is the focal point of our analysis.

Prévost, before Balzac, Flaubert, and Zola, is a great novelist of space, for one finds, in his literary universe, a spatial diversity which does not only build the novel, but is also submitted to a logical order in the narrative dynamic. The first episode of Manon Lescaut, for instance, opens with the scene of a street, in which "L'Homme de qualité," in the middle of a mad crowd, seeks tirelessly to satisfy his curiosity. The diverse functions of the space of the text fit into the images of the Prévostian writing on which the space is built. ${ }^{1}$ The street is the center of the spectacle. Here des Grieux emerges for the first time in the literary action by paying special attention to Manon before her deportation to America.

In the succession of the narrative scenes, Prévost alternates the spatial sites and their specific features. In the second scene of Manon Lescaut, one

1 As Louis Marin writes: "Le langage, le discours se donne dans le texte comme une architecture de niveaux et de plans, qui établit entre eux un système complexe de relations, d'englobements et de correspondances, d'enveloppements et d'isomorphies." See Utopies: jeux d'espaces, Paris, Les Éditions de Minuit, 1973, p. 149. 
finds des Grieux under house arrest, which is a private space. Subsequently, the narration offers to Prévost's reader a closed and public space: the SaintLazare's jail. Des Grieux's incarceration becomes the generator of the narrative unity, since it provides the background for elements of the story like conflict, violence in the jail, and the death of one of the jail servants. By situating his main character in two different and opposite spaces in the first two scenes in Manon Lescaut, the novelist creates a proportional spatial rigor, which also marks a symmetrical aspect of the story. One also finds the same spatial aspect in Cleveland with the transition of the characters, Gélin, Johnston, and Bridge, from a dysphoric place to the long road leading them to America.

Besides the proportional spatial rigor in Prévost's novels, one also notes what one can call a spatial closure. Indeed, the first episode in Manon Lescaut starts in Paris with the return of Des Grieux to Paris in the last episode after living in America for awhile. Similarly, the novelist repeats the same narrative devices in the third book of Cleveland, in which the literary action begins in an open and public space in Havana, and ends in the same initial space with the return of the Prévostian characters to Havana. The spatial closure reveals Prévost's ingenuity, by establishing a relationship between the space of the book and the narrative discourse.

In its textual materiality, the space of the book, with its diverse spatial representations and the characters' dreaming of different places, provokes various reflections. In Prévost's novels, one observes all sorts of geographical spaces which characterize his protagonists' lives, like jails, deserts, seas, slave markets, gladiatorial battlegrounds. The various spaces in themselves represent places of sorrow and suffering. With the different vicissitudes to which Prévost's protagonists are exposed, his novels contain a social space characterized by the presence of people through the streets of the great cities like Paris, Lisbon, Madrid, and London. The landscape could be seen as a sort of social kaleidoscope. It has a symbolic pyschological value founded on the characters' behavior. The landscape painter always fits into the characters' actions, which mostly take place overseas:

Voici l'ordre que les personnes de condition observent à Tumbrigde. On vient le matin sur les sept heures, en déshabillé, pour prendre les eaux, et l'on se promène une ou deux sur le Walk. On déjeûne ensuite avec du thé ou du chocolat dans les maisons de café $[\ldots .$. On se trouve quelquefois cinquante ou soixante d'une même bande à déjeûner dans une même salle [...] Après le

\section{LittéRéalité}


déjeûner, on recommence à se promener. Quelques-uns jouent aux jeux de hasard. La prière sonne vers midi; et les dévots vont à l'église, qui est bâtie exprès au bout du Walk. [...] Vers les quatre heures, on voit revenir tout le monde en foule [...] (253)

From the outset of the paragraph, the first sentence, which is in itself tautological, reveals the place of the literary action and the descriptive organization of the scene. Its effects of figuration create new discoveries of the space of Tumbridge, which is transformed into different spaces of socialization. Among the different recreational and meeting places, some are near and others are distant. They congregate around the neutral pronoun "on" which represents a multitude of visitors at Tumbridge. The space of the text is focused on the act of writing. It suggests the articulations of the places, and is at the service of the narrative dynamic. The movements of the characters invigorate the scene, which is temporally intensified with the arrival of a multitude of people to the party. It is also interesting to note the narrative technique used by Prévost throughout this passage to unite his characters. With the various recreational activities to which they are attracted, the characters find themselves in different games rooms, and begin to settle in Tumbridge. It is a delightful place. Tumbridge is a space of entertainment where the visitors spend their major time during their sojourn. "On danse jusqu'à la pointe du jour." (253) In this internal space, there exists many recreational sites which allow people to socialize every day like the garden described in La Nouvelle Héloïse:

Il y a, trois fois la semaine, un bal public dans une grande salle, qui n'est que pour cet usage. Là, tous les rangs sont confondus; car on $y$ voit les grisettes à côté des duchesses, sans que personne ait droit de s'informer d'où l'on vient ni qui l'on est." (253)

Basically, the space and subject can be comprehened from the recreational activities which provoke the relative fusion of social classes. The neutral pronoun "on," which represents both the hero and the diversity of visitors in Tumbridge, indicates to the reader this relative fusion of social groups. When the narrator says "on," he also refers to himself. One deduces that the space of the text of the novel, Mémoires et aventures d'un homme de qualité, in only one page, contains the principal elements of a great narrative scene.

With the different adventures of Prévost's characters, his novels invite the reader to observe their sad experiences, which are linked fundamentally 
to the spatiality. The geographical space of the desert of Louisiana in which des Grieux and Manon find themselves after leaving New Orleans shows us the difficulties experienced by the two lovers. It is the same for Axminster and his companions in the vast desert of Drexera, where they are the prey of animals and uncivilized people. The dysphoric space of the desert in which many Prévostian protagonists are living creates in the reader a suspense of time, for one acknowledges, from the first page of the scene, the beginning of a long spiritual journey.

In the literary compostion, such a narrative aspect constitutes, accordind to Roland Barthes' expression "le plaisir du texte,"2 because the reader is anxious to know the progression and the end of the narrative concerning the characters' future. Similarly, in $H$ istoire d'une grecque moderne, the first official meeting between Ferriol and Théophé in a private study also creates in the reader "un horizon d'attente," since the first scene of the novel shows us that Ferriol passionately loves her, although he tries to hide his feelings. Subsequently, his passion leads him to free Théophé from Chéribier's seraglio in order to make her his mistress. His story, which, at the outset, is perceived as a trial against Théophé, arouses a desire to know the heroine's destiny. This incites the reader to find what Roland Barthes calls "le plus vite les lieux brûlants de l'anecdote."

In Histoire d'une Grecque moderne, one finds a productive dialectic aspect founded on the conflict between Ferriol and Théophé. Their dispute extends mostly the second part of the novel, which constitutes the narrative dynamic. The latter creates in the reader a space of pleasure like the scenes describing the relationship between Julie and Saint-Preux in $\mathrm{La}$ Nouvelle Héloïse. The conflictual scenes in Prévost's novels create in the reader the suspense, or what Barthes calls "une imprévision de la jouissance" 4 of the space of the text, for he wants to know how the conflict will be resolved.

On the other hand, the spatiality of the writing and the pleasure of the text in Prévost are also revealed through stylistic figures. The Prévostian rhetoric provokes what we may call the aesthetic of seduction and enjoyment founded on language. Let us consider the following passage in Mémoires et aventures d'un homme de qualité:

2 See Barthes, Roland, Le Plaisir du texte, Paris, Seuil, 1973.

3 Ibid., p. 21.

4 Ibid., p. 11.

\section{LittéRéalité}


Je n'ai plus que des soupirs et des pleurs à leur offrir. Je sens que toutes les plaies de mon coeur vont se rouvrir, et qu'elles sont prêtes à saigner. Quatorze ans entiers passés dans la douleur n'ont pu m'accoutumer à ma perte, qui semble se renouveler tous les jours. (96)

From a linguistic viewpoint, one discovers in this passage two fundamental rhetorical aspects: a poetic aspect and an aspect of figures of elocution. ${ }^{5}$ The first aspect, on one hand, concerns the assonance of the verbs "offrir" and "rouvrir"; and, on the other hand, the assonance of the words "pleurs," "coeur," and "douleur." The unity of the paragraph, in light of its semantic and phonic rhythms, can be perceived as poetic prose. ${ }^{6}$

The second aspect involves the alliterations produced by the words "s/ou/pirs," "r/ou/vrir," "d/ou/leur," "acc/ou/tumer," "ren/ou/veler," and "j/ou/rs." Those various rhetorical aspects give to Prévostian writing a linguistic musical dimension. It is also interesting to note that there is not only a relation from the auditory perspective among the words, but also from the semantic perspective. Semantically, the vocabulary, which suggests sadness and suffering, is pathetic. The figures of locution with consonances in the passage are plentiful, which reinforces their poetic features. There exists in Prévost's novels many examples. Let us limit ourselves to this one, which is, in some respects, similar to the previous one cited:

[...] j'eus la douceur de la trouver sensible à cette tendre caresse. Un soupir, qui lui échappa malgré elle, me fit encore juger plus favorablement de ce qui se passait dans son coeur. Pendant toute la route je tins sa main serrée dans les miennes, et je crus remarquer qu'elle y trouvait autant de douceur que moi. Je ne luis dis pas un mot qui ne fût mêlée de quelque marque de tendresse, et mes discours même, quoiqu'aussi mesurés que mes actions par un goût de bienséance qui m’a toujours été naturel, se ressentirent continuellement du feu qui prenait plus de force que jamais dans mon coeur. Si Théophé se défendit quelquefois contre l'ardeur de mes expressions, ce ne fut point par des mépris ni par des rigueurs." (47)

5 See Fontanier, Pierre, Les Figures du discours, Paris, Flammarion, 1977.

6 See Kristeva, Julia, La Révolution du langage poétique, Paris, Seuil, 1974, pp. 209-263. 
One finds in this passage the same aesthetic and rhetorical features examined in the previous one. The assonances ("douceur," "coeur," "ardeur," "rigueurs," "caresse," "tendresse," "discours," and "toujours") are abundant, which gives to the unity of the paragraph a great poetic value. The alliterations ("r/ou/te," "d/ou/ceur," "s/ou/pir" "g/oû/t," "disc/ou/rs," "t/ou/j/ou/rs,") reinforce it, for they are as abundant as the assonances. The difference between the two passages is that the vocabulary of the first one characterizes sadness, while the second one reveals a sentimental aspect. That summarizes the relationship between Ferriol and Théophé. It is obvious that the space of the text fits into the language and experience of writing of the novelist. As explains Louis Marin: “[...] l'espace, lorsqu'il est dit, provoque nécessairement des effets dans le discours, effets par lesquels il se constitue en texte: en espace de texte."

In light of the Prévostian places and spaces previously examined, one realizes that they play, like the trips and migration of characters, a prominent role in his literary composition. They constitute the core of the literary action. In each narrative unity of Prévost's novels, one finds a spatial typology on which the literary scene is built.

\section{Works cited}

Barthes, Roland, Le Plaisir du texte, Paris, Seuil, 1973.

Fontanier, Pierre, Les Figures du discours, Paris, Flammarion, 1977.

Kristeva, Julia, La Révolution du langage poétique, Paris, Seuil, 1974.

Marin, Louis, Utopiques: jeux d'espaces, Paris, Les Éditions de Minuit, 1973.

Prévost, Antoine-François, Manon Lescaut, Paris, Éd. Pocket, 1979. , Histoire d'une Grecque monderne, Paris, PUG, 1977.

- Mémoires et anventures d'un homme de qualité, Paris, PUG, 1997. , Cleveland. Paris, PUG, 1977.

Rousseau, Jean-Jacques, Julie ou La Nouvelle Héloïse, Paris, Flammarion, 1978.

7 Utopiques: jeux d'espaces, op. cit., 1973, p. 152. 